\title{
Primary hypothyroidism in dogs is associated with elevated GH release
}

\author{
W M Lee, M Diaz-Espineira, J A Mol, A Rijnberk \\ and $\mathbf{H} \mathbf{S}$ Kooistra \\ Department of Clinical Sciences of Companion Animals, Faculty of Veterinary Medicine, Utrecht University, Yalelaan 8, PO Box 80·154, \\ NL-3508 TD Utrecht, The Netherlands \\ (Requests for offprints should be addressed to W M Lee; Email: W.M.Lee@vet.uu.nl)
}

\begin{abstract}
The pulsatile secretion patterns of GH were investigated in seven beagle bitches by collecting blood samples every $10 \mathrm{~min}$ for $6 \mathrm{~h}$ during euthyroidism and 1.5 years after induction of primary hypothyroidism. Hypothyroidism was induced by surgical removal of the thyroid gland and subsequent destruction of any remnant thyroid tissue by oral administration of sodium $\left[{ }^{131} \mathrm{I}\right]$ iodide. Some of the physical changes observed in the dogs with primary hypothyroidism mimicked those of acromegaly. During both euthyroidism and hypothyroidism GH was secreted in a pulsatile fashion. The mean ( \pm s.E.M.) basal plasma GH concentration was significantly higher $(P=0.003)$ in the hypothyroid state $(4.1 \pm 1.6 \mu \mathrm{g} / \mathrm{l})$ than in the euthyroid state $(1 \cdot 2 \pm 0 \cdot 4 \mu \mathrm{g} / \mathrm{l})$. Likewise, the mean area under the curve (AUC) for $\mathrm{GH}$ above the zero-level during hypothyroidism $(27 \cdot 0 \pm 10 \cdot 0 \mu \mathrm{g} / 1 \times 6 \mathrm{~h})$ was significantly higher $(P=0.004)$ than that during euthyroidism $(11 \cdot 7 \pm 2 \cdot 0 \mu \mathrm{g} / 1 \times 6 \mathrm{~h})$. The mean AUC for $\mathrm{GH}$ above
\end{abstract}

the baseline was significantly lower $(P=0.008)$ during hypothyroidism $(2 \cdot 4 \pm 0 \cdot 8 \mu \mathrm{g} / 1 \times 6 \mathrm{~h})$ than during euthyroidism $(4.5 \pm 1.8 \mu \mathrm{g} / 1 \times 6 \mathrm{~h})$, whereas there was no significant difference in $\mathrm{GH}$ pulse frequency. The mean plasma IGF-I level was significantly higher $(P<0 \cdot 01)$ in the hypothyroid state $(169 \pm 45 \mu \mathrm{g} / \mathrm{l})$ than in the euthyroid $(97 \pm 15 \mu \mathrm{g} / \mathrm{l})$. The results of this study demonstrate that primary hypothyroidism in dogs is associated with elevated basal GH secretion and less GH secreted in pulses. This elevated GH secretion has endocrine significance as illustrated by elevated plasma IGF-I levels and some physical changes mimicking acromegaly. It is discussed that the increased GH release in hypothyroid dogs may be the result of the absence of a response element for thyroid hormone within the canine pituitary GH gene and alterations in supra-pituitary regulation.

Journal of Endocrinology (2001) 168, 59-66

\section{Introduction}

Growth hormone $(\mathrm{GH})$ is secreted by the pituitary anterior lobe in a pulsatile fashion under the regulation of two hypothalamic peptides: GH-releasing hormone (GHRH) stimulates GH secretion, while somatostatin (SS) inhibits GH release. This regulatory system is influenced by negative feedback from peripherally formed growth factors, particularly insulin-like growth factor-I (IGF-I) (Hartman et al. 1993, Bermann et al. 1994). In addition, a recently identified GH-releasing peptide, called Ghrelin, is likely to play a role in the regulation of pituitary $\mathrm{GH}$ secretion (Kojima et al. 1999). The amplitude and frequency of GH secretory pulses are regulated by a complex array of external and internal stimuli including age (Corpas et al. 1993, Arvat et al. 1997), gender (Van den Berg et al. 1996), oestrous cycle phase (Faria et al. 1992), genetic background (Mendlewicz et al. 1999), nutritional status (Riedel et al. 1995), sleep (Matsuno et al. 1998), disease status (Frohman et al. 1992) and body composition

(Ahmad et al. 1989). In addition, hormones such as glucocorticoids and thyroid hormones (Devesa et al. 1992) influence the pulsatile secretion pattern of $\mathrm{GH}$.

In rats, thyroid hormones are necessary to maintain both pulsatile and induced GH secretion (Martin et al. 1985). The GH secretory profile has been found to shift from a low-frequency, high-amplitude pattern in euthyroid rats to a high-frequency, low-amplitude pattern in rats with mild hypothyroidism induced by methimazole (Bruhn et al. 1992). Severe hypothyroidism in rats is associated with markedly reduced circulating GH levels (Varela et al. 1991, Santini et al. 1993, Mizobuchi et al. 1996, Tam et al. 1996, Osorio et al. 1998), abolished GH bursts (Takeuchi et al. 1978, Katakami et al. 1986), blunted GH response to GHRH (Williams et al. 1985, Tam et al. 1996) and decreased pituitary content of mRNA encoding for GH (Martinoli \& Pelletier 1989, Lloyd et al. 1990, Tam et al. 1996). In addition, hypothyroidism in rats causes a reduction in pituitary GH content (Szabo et al. 1985, Katakami et al. 1986, Wood et al. 1987, Lloyd et al. 1990, Varela 
et al. 1991), pituitary GHRH receptor mRNA (Tam et al. 1996, Korytko \& Cuttler 1997), hypothalamic SS content (Tam et al. 1996) and hypothalamic SS mRNA (Tam et al. 1996).

In humans with primary hypothyroidism, the peak GH values after GHRH administration are low (Root et al. 1985, Williams et al. 1985, Damjanovic et al. 1996, Pimentel-Filho et al. 1997). Severe primary hypothyroidism in children is associated with attenuated spontaneous GH secretion (Buchanan et al. 1988, Chernausek \& Turner 1989, Nishi et al. 1989). In line with these observations are the findings of in vitro studies in cell lines derived from human GH-secreting pituitary tumours, which revealed that thyroid hormones promote $\mathrm{GH}$ mRNA accumulation (Chomczynski et al. 1993) and GH release (Lamberts et al. 1984). The stimulatory effect of thyroid hormones on GH mRNA accumulation has been ascribed to transcriptional activation of the human $\mathrm{GH}$ gene (Chomczynski et al. 1993).

Information with regard to changes in pituitary $\mathrm{GH}$ secretion during primary hypothyroidism in other mammals is scarce. Low circulating GH levels have been reported in hypothyroid pigs (Morovat \& Dauncey 1998). In contrast, hypothyroidism did not affect spontaneous GH secretion in sheep and steers, although the response to stimulation with GHRH was reduced in hypothyroid sheep (Elsasser et al. 1992, Fletcher \& Clarke 1994).

In dogs, primary hypothyroidism is one of the most common endocrine diseases. The signs and symptoms include weight gain, lethargy and dermatological changes such as truncal alopecia and skin thickening due to mucopolysaccharide accumulation (Feldman \& Nelson 1996, Rijnberk 1996). Changes in the GH secretion pattern might contribute to the features observed in dogs with primary hypothyroidism but information on the pulsatile GH secretion pattern in dogs with primary hypothyroidism is lacking. Therefore, we investigated the $6 \mathrm{~h}$ pulsatile GH secretion pattern both before and after induction of hypothyroidism in seven beagle dogs.

\section{Materials and Methods}

Dogs

Seven neutered (ovariectomized) beagle bitches entered the study at the age of 3 years. All bitches were accustomed to the laboratory environment and procedures such as the collection of blood. They were housed in individual cages, fed a commercial dog food twice a day, and had free access to water. On the days on which blood samples were collected, the dogs were fed their usual commercial dog food between 0900 and $0930 \mathrm{~h}$.

Euthyroidism was confirmed by the finding of basal and bovine thyrotrophin (TSH)-stimulated plasma thyroxine concentrations within their respective reference range, a plasma TSH concentration within the reference range, a normal image of the thyroid glands obtained by scintigraphy using radioactive pertechnetate $\left({ }^{99} \mathrm{~m}_{\mathrm{TcO}}{ }^{-}\right)$, and, eventually, by the finding of normal thyroid gland tissue by histological examination after thyroidectomy.

Primary hypothyroidism was induced by surgical removal of the thyroid gland, leaving the external parathyroid glands in situ. About 3 months later, the dogs were fed a low-iodine diet (meat and white bread) for 3 weeks to increase the iodine uptake by any remnant thyroid tissue, which was then destroyed by administering $5 \mathrm{mCi}(=185$ $\mathrm{MBq})$ of sodium $\left[{ }^{131} \mathrm{I}\right]$ iodide orally.

The present study was part of a larger study in which we investigated the effect of long-term primary hypothyroidism on pituitary TSH secretion in dogs.

\section{Sample collection}

Blood samples for determining the plasma concentration of $\mathrm{GH}$ were collected at $10 \mathrm{~min}$ intervals between 0800 and $1400 \mathrm{~h}$. This was done 1 month prior to the surgical thyroidectomy and again 1.5 years later. Blood samples were collected by jugular venepuncture and immediately placed in chilled EDTA-coated tubes, and centrifuged. Plasma was stored at $-20{ }^{\circ} \mathrm{C}$ until assayed.

\section{Hormone determination}

Plasma TSH concentrations were determined by a homologous solid-phase, two-site chemiluminescence enzyme immunometric assay (Immulite canine TSH; Diagnostic Products Corporation (DPC), Los Angeles, CA, USA) in accordance with the instructions of the manufacturer. The intra-assay coefficients of variation were $5 \cdot 0,4 \cdot 0$ and $3 \cdot 8 \%$ at TSH levels of $0 \cdot 20,0.50$ and $2 \cdot 6 \mu \mathrm{g} / 1$ respectively. The intra-assay coefficients of variation were 6.3 and $8.2 \%$ at TSH levels of 0.16 and $2 \cdot 8 \mu \mathrm{g} / 1$ respectively. The lowest detectable amount of TSH was $0.03 \mu \mathrm{g} / 1$.

Plasma total thyroxine concentrations were determined by a homologous solid-phase, chemiluminescence enzyme immunoassay (Immulite canine Total T4; DPC) in accordance with the instructions of the manufacturer and validated for the $\operatorname{dog}$ by Bruner et al. (1998). The intra-assay coefficients of variation were $13 \cdot 8$ and $8 \cdot 2 \%$ at thyroxine levels of 8 and $25 \mathrm{nmol} / 1$ respectively. The lowest detectable amount of thyroxine was $1.5 \mathrm{nmol} / \mathrm{l}$.

Plasma GH concentrations were measured by a homologous RIA as described previously (Eigenmann \& Eigenmann 1981). The intra- and inter-assay coefficients of variation were $3 \cdot 8$ and $7 \cdot 2 \%$ respectively, and the sensitivity of the assay was $0 \cdot 3 \mu \mathrm{g} / \mathrm{l}$.

Plasma IGF-I concentrations were measured by a heterologous RIA as described previously (Nap et al. 1993). The intra- and inter-assay coefficients of variation were $4 \cdot 7$ 
and $15.6 \%$ respectively, at an IGF-I concentration of $175 \mu \mathrm{g} / 1$. The sensitivity of the assay was $6 \mu \mathrm{g} / \mathrm{l}$.

\section{Data analysis}

The $6 \mathrm{~h}$ secretion patterns of GH were analysed using the Pulsar program developed by Merriam \& Wachter (1982). The program identifies secretory peaks by height and duration from a smoothed baseline, using the assay S.D. as a scale factor. The cut-off parameters G1-G5 of the Pulsar program were set at $3.98,2.40,1.68,1.24$ and 0.93 times the assay S.D. as criteria for accepting peaks 1, 2, 3, 4 and 5 points wide respectively, resulting in a false-positive error rate of less than $5 \%$. The smoothing time, a window used to calculate a running mean value, was set at $5 \mathrm{~h}$. The weight assigned to peaks was $0 \cdot 05$. The $A, B$ and $C$ values of the Pulsar program, used to calculate the variance of the assay, were set at $\mathrm{A}=0, \mathrm{~B}=7 \cdot 2$ and $\mathrm{C}=5 \cdot 0$. The values extracted from the Pulsar analyses included the overall mean of the smoothed baseline, the number of peaks, the area under the curve (AUC) above the zero-level and the AUC above the baseline.

Differences in parameters during euthyroidism and hypothyroidism were evaluated by Student's $t$-test for related samples (two-tailed). Since the data were not assumed to be normally distributed, differences in pulse frequency were determined by non-parametric analysis, using Wilcoxon's signed rank test. Values are expressed as means \pm S.E.M. $P<0.05$ was considered significant.

\section{Ethics of experimentation}

The experiments in this study were approved by the Ethical Committee of the Faculty of Veterinary Medicine, Utrecht University.

\section{Results}

The mean body weight during hypothyroidism $(20 \cdot 1 \pm 1 \cdot 4 \mathrm{~kg})$ was significantly higher $(P=0 \cdot 002)$ than that during euthyroidism $(14.5 \pm 0.7 \mathrm{~kg})$. In all dogs, induction of primary hypothyroidism also resulted in marked exercise intolerance and skin changes such as thick folding. In all dogs, alopecia and hyperpigmentation were noticeable especially on the bridge of the nose. In four of the dogs there appeared to be some maxillar prognathia with widening of the interdental spaces.

At 1.5 years after induction of primary hypothyroidism plasma thyroxine concentrations were low $(<2 \mathrm{nmol} / \mathrm{l})$ as compared with the euthyroid state $(18.3 \pm 1.7 \mathrm{nmol}$, $P<0 \cdot 001)$. The mean plasma TSH level rose $(P=0 \cdot 01)$ from $0.11 \pm 0.03 \mu \mathrm{g} / 1$ prior to thyroidectomy to $1 \cdot 4 \pm 0 \cdot 38 \mu \mathrm{g} / 1$ during hypothyroidism.

$\mathrm{GH}$ was secreted in a pulsatile fashion both before and after induction of primary hypothyroidism. Examples of
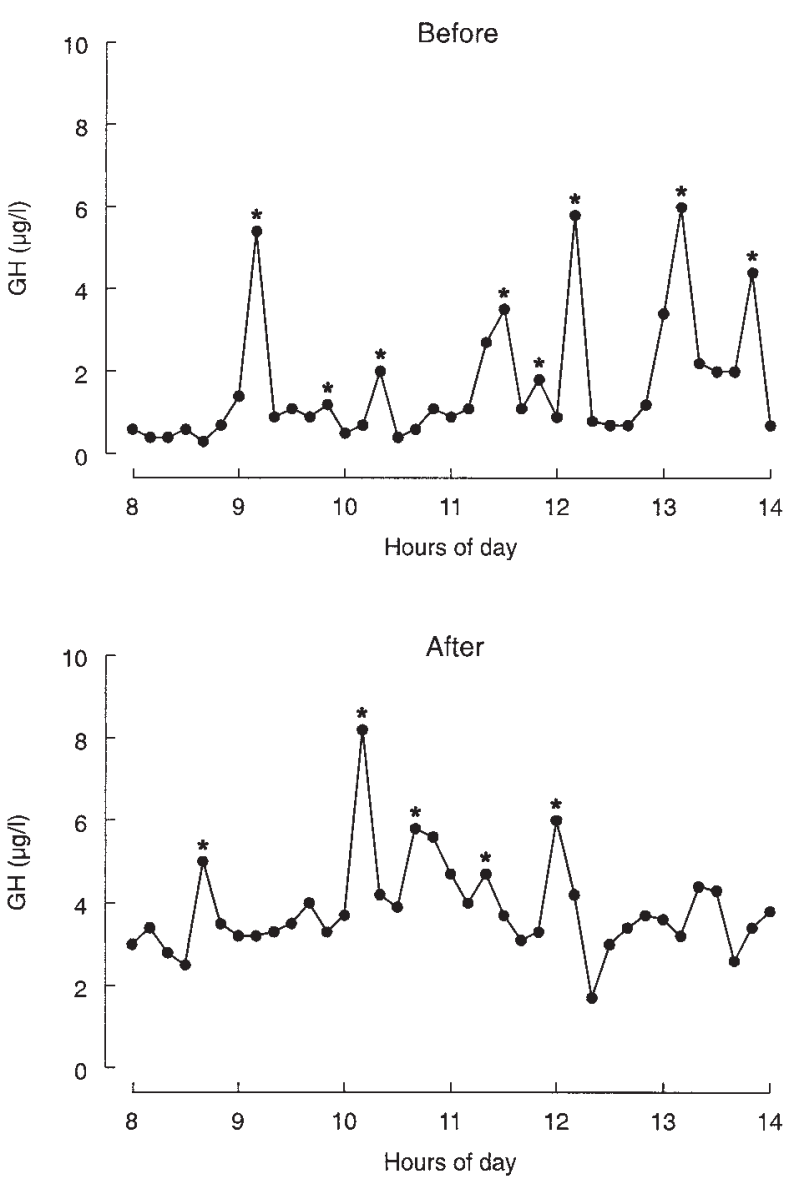

Figure 1 The $6 \mathrm{~h}$ secretory profiles of $\mathrm{GH}$ in a beagle bitch during euthyroidism (before) and during hypothyroidism (after). Significant GH pulses, calculated by the Pulsar program, are indicated by an asterisk.

the pulsatile secretion patterns of $\mathrm{GH}$ during euthyroidism and hypothyroidism are shown in Fig. 1. The mean basal plasma GH level in the hypothyroid state $(4 \cdot 1 \pm 1 \cdot 6 \mu \mathrm{g} / \mathrm{l})$ was significantly higher $(P=0.003)$ than that during euthyroidism $(1 \cdot 2 \pm 0 \cdot 4 \mu \mathrm{g} / \mathrm{l})$. Likewise, the mean AUC for GH above the zero-level during hypothyroidism $(27 \cdot 0 \pm 10 \cdot 0 \mu \mathrm{g} / 1 \times 6 \mathrm{~h})$ was significantly higher $(P=$ $0.004)$ than that during euthyroidism $(11.7 \pm 2.0 \mu \mathrm{g} /$ $1 \times 6 \mathrm{~h}$ ). In contrast, the AUC for GH above the baseline was significantly lower $(P=0 \cdot 008)$ during hypothyroidism $(2 \cdot 4 \pm 0.8 \mu \mathrm{g} / 1 \times 6 \mathrm{~h})$ than during euthyroidism $(4.5 \pm$ $1.8 \mu \mathrm{g} / 1 \times 6 \mathrm{~h}$ ). The $\mathrm{GH}$ pulse frequency in the $6 \mathrm{~h}$ secretory patterns varied from one to ten peaks prior to thyroidectomy, and from two to five peaks after induction of hypothyroidism (Table 1). The mean GH pulse frequency in the euthyroid state $(6 \pm 3$ pulses $/ 6 \mathrm{~h})$ was higher than that in the hypothyroid $(4 \pm 1$ pulses $/ 6 \mathrm{~h})$, but this difference was not statistically significant $(P=0 \cdot 24)$. The mean plasma IGF-I level was significantly higher 
Table 1 Characteristics of the $6 \mathrm{~h}$ secretory profiles of GH and the plasma IGF-I levels in seven beagle bitches during euthyroidism and hypothyroidism. Basal $\mathrm{GH}$, basal plasma $\mathrm{GH}$

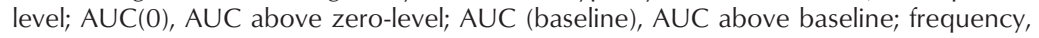
$\mathrm{GH}$ pulse frequency per $6 \mathrm{~h}$. The values are expressed as means \pm S.E.M.

\begin{tabular}{|c|c|c|c|c|c|}
\hline & $\begin{array}{l}\text { Basal GH } \\
(\mu \mathrm{g} / \mathrm{l})\end{array}$ & $\begin{array}{l}\operatorname{AUC}(\mathbf{0}) \\
(\mu \mathrm{g} / \mathrm{I} \times 6 \mathrm{~h})\end{array}$ & $\begin{array}{l}\text { AUC(baseline) } \\
(\mu \mathrm{g} / \mathrm{I} \times 6 \mathrm{~h})\end{array}$ & $\begin{array}{l}\text { Frequency } \\
\text { (pulses/6 h) }\end{array}$ & $\begin{array}{l}\text { IGF-I } \\
(\mu \mathrm{g} / \mathrm{l})\end{array}$ \\
\hline \multicolumn{6}{|l|}{ Dog 1} \\
\hline Euthyroid & $1 \cdot 2$ & $9 \cdot 0$ & $1 \cdot 8$ & 1 & 91 \\
\hline Hypothyroid & $2 \cdot 6$ & $17 \cdot 9$ & $2 \cdot 2$ & 5 & 169 \\
\hline \multicolumn{6}{|l|}{ Dog 2} \\
\hline Euthyroid & $0 \cdot 8$ & $10 \cdot 1$ & $5 \cdot 4$ & 8 & 121 \\
\hline Hypothyroid & $3 \cdot 5$ & $23 \cdot 3$ & $2 \cdot 5$ & 5 & 193 \\
\hline \multicolumn{6}{|l|}{ Dog 3} \\
\hline Euthyroid & $1 \cdot 8$ & $13 \cdot 2$ & $2 \cdot 7$ & 4 & 91 \\
\hline Hypothyroid & $4 \cdot 6$ & $29 \cdot 1$ & $1 \cdot 7$ & 4 & 169 \\
\hline \multicolumn{6}{|l|}{ Dog 4} \\
\hline Euthyroid & $1 \cdot 5$ & $13 \cdot 4$ & $4 \cdot 2$ & 3 & 111 \\
\hline Hypothyroid & $3 \cdot 1$ & $20 \cdot 8$ & $2 \cdot 2$ & 5 & 100 \\
\hline \multicolumn{6}{|l|}{ Dog 5} \\
\hline Euthyroid & $1 \cdot 4$ & $13 \cdot 3$ & $5 \cdot 1$ & 8 & 100 \\
\hline Hypothyroid & $7 \cdot 4$ & $47 \cdot 2$ & $3 \cdot 1$ & 2 & 227 \\
\hline \multicolumn{6}{|l|}{ Dog 6} \\
\hline Euthyroid & $1 \cdot 0$ & $13 \cdot 1$ & $7 \cdot 3$ & 10 & 76 \\
\hline Hypothyroid & $4 \cdot 4$ & $30 \cdot 1$ & $3 \cdot 6$ & 5 & 202 \\
\hline \multicolumn{6}{|l|}{ Dog 7} \\
\hline Euthyroid & $0 \cdot 9$ & $9 \cdot 8$ & $4 \cdot 6$ & 9 & 92 \\
\hline Hypothyroid & $3 \cdot 2$ & $20 \cdot 3$ & $1 \cdot 4$ & 4 & 121 \\
\hline
\end{tabular}

$(P=0.009)$ in the hypothyroid state $(169 \pm 45 \mu \mathrm{g} / \mathrm{l})$ than in the euthyroid $(97 \pm 15 \mu \mathrm{g} / \mathrm{l})$.

\section{Discussion}

The results of this study demonstrate that in dogs primary hypothyroidism is associated with elevated GH secretion. In contrast to observations in other mammals, in dogs both basal and integrated GH levels were significantly higher in hypothyroidism than in euthyroidism. In some mammals, such as sheep and steers, primary hypothyroidism does not seem to affect GH secretion (Elsasser et al. 1992, Fletcher \& Clarke 1994), whereas in rats (Varela et al. 1991, Santini et al. 1993, Mizobuchi et al. 1996, Tam et al. 1996, Osorio et al. 1998) and pigs (Morovat \& Dauncey 1998) primary hypothyroidism is associated with low circulating $\mathrm{GH}$ levels.

The human pituitary GH gene contains a positive thyroid hormone response element (TRE) (Chomczynski et al. 1993). In line with this observation, experimentally induced thyroid hormone excess leads to increased $\mathrm{GH}$ secretion in healthy men (Lovejoy et al. 1997). It is likely that the low thyroid hormone levels of hypothyroidism will result in a low expression of pituitary GH in species with a positive TRE in the GH gene. Indeed, in hypothyroid rats both decreased pituitary content of GH mRNA
(Martinoli \& Pelletier 1989, Lloyd et al. 1990, Tam et al. 1996) and reduced pituitary GH content (Szabo et al. 1985, Katakami et al. 1986, Wood et al. 1987, Lloyd et al. 1990, Varela et al. 1991) have been reported. The lack of a decrease in GH biosynthesis and release in dogs with primary hypothyroidism may be explained by the absence of a positive TRE within the canine GH gene. Alternatively, the presence of a negative TRE within the $\mathrm{GH}$ gene would result in a reduced suppression of GH expression, i.e. elevated $\mathrm{GH}$ production and secretion in hypothyroid animals. The presence of negative TREs has been demonstrated in different genes, for example in the TSH-releasing hormone (TRH) gene (Hollenberg et al. 1995), the TSHbeta gene (Breen et al. 1997) and in keratin genes (Radoja et al. 1997). Sequence analysis of the promoter region and intron 1 of the canine GH gene (Lantinga-van Leeuwen \& Mol 2000) has not demonstrated the existence of a TRE in this species. However, gel shift assays or footprints have not been performed yet in the dog.

Apart from direct effects in transcription of the $\mathrm{GH}$ gene, it is possible that hypothyroidism affects $\mathrm{GH}$ release via an influence on the hypothalamic hormones GHRH and SS. In rats, primary hypothyroidism is associated with a reduced hypothalamic content of SS mRNA and SS (Tam et al. 1996). Moreover, thyroidectomy in rats leads to decreased SS release from the hypothalamus (Mizobuchi 
et al. 1996). Therefore, it may be postulated that the hypothalamic SS secretion is also reduced in dogs with primary hypothyroidism, which may in turn explain the elevated basal GH secretion in this species.

Another option that should be discussed concerns the feedback signal of the low thyroxine concentration on the release of hypothalamic TRH. In healthy humans administration of TRH does not result in appreciable changes in plasma GH levels (Faggiano et al. 1985, Coiro et al. 1994, Hanew et al. 1995), whereas in euthyroid rats stimulation with TRH elicits no (Varela et al. 1991) or only a small transient (Szabo et al. 1985) rise in plasma GH levels. In contrast, in humans and rats with primary hypothyroidism TRH administration results in significantly increased plasma GH levels (Faggiano et al. 1985, Varela et al. 1991, Coiro et al. 1994, Hanew et al. 1995). In line with these observations, Konaka et al. (1997) have demonstrated the expression of TRH receptor mRNA in rat somatotrophs. The paradoxical response of GH to TRH in primary hypothyroidism may be caused by the relative deficiency of SS discussed in the previous paragraph, as SS infusion inhibits the GH response to TRH in hypothyroid human patients (Baldini et al. 1992). Also, in healthy dogs TRH administration does not result in changes in the plasma GH level (Rutteman et al. 1987). However, so far there is no information on the effect of TRH on GH secretion in dogs with primary hypothyroidism. Nevertheless, it may be hypothesized that also in hypothyroid dogs the elevated release of TRH not only causes increased TSH secretion but may also give rise to elevated GH secretion.

In agreement with previous publications (Takahashi et al. 1981, French et al. 1987, Kooistra et al. 2000), in the present dogs GH was secreted in a pulsatile fashion. The results demonstrate that primary hypothyroidism in dogs is associated with changes in the pulsatile secretion pattern of GH. The mean AUC for GH above the baseline was significantly lower during hypothyroidism than in the euthyroid state. In combination with an unchanged GH pulse frequency this indicates that in hypothyroid dogs less $\mathrm{GH}$ is released per pulse. This may be explained by a blunted response of the pituitary somatotrophs to GHRH. Indeed, administration of GHRH results in a markedly reduced GH response in hypothyroid humans (Root et al. 1985, Williams et al. 1985, Damjanovic et al. 1996, Pimentel-Filho et al. 1997), hypothyroid rats (Williams et al. 1985, Tam et al. 1996) and hypothyroid sheep (Fletcher \& Clarke 1994). Moreover, in hypothyroid rats a reduced pituitary content of GHRH receptor mRNA has been reported (Tam et al. 1996, Korytko \& Cuttler 1997).

The reduction in GH secreted in pulses in the hypothyroid dogs may also be explained by increased IGF-I secretion. The results demonstrate that the plasma IGF-I levels were significantly higher in hypothyroidism than in euthyroidism. Elevated circulating levels of IGF-I have been reported to inhibit pulsatile pituitary GH secretion
(Hartman et al. 1993), mainly by attenuation of spontaneous GH pulse amplitude (Bermann et al. 1994).

Finally, the reduction in $\mathrm{GH}$ secreted in pulses in hypothyroid dogs may be ascribed to extra-pituitary secretion of GH. Decreased GH pulsatility has been reported in women during the second half of pregnancy (Eriksson et al. 1989). In these women the loss of GH pulsatility is due to the release of a placental GH variant (Eriksson et al. 1989). In addition, a reduction in GH secreted in pulses has been reported in bitches during the progesterone phase of the oestrous cycle (Kooistra et al. 2000) and in bitches treated with progestagens (Watson et al. 1987). Endogenous progesterone and exogenous progestagens in these bitches result in excessive $\mathrm{GH}$ secretion (Eigenmann et al. 1983) originating from foci of hyperplastic ductular epithelium of the mammary gland (Selman et al. 1994, Van Garderen et al. 1997). The loss of GH pulsatility in both humans and bitches has been ascribed to the negative feedback effects of nonepisodically secreted extra-pituitary GH. However, it is very unlikely that this mechanism was operational in the present dogs as only ovariectomized bitches were used.

The endocrine effects of GH can be divided into rapid catabolic actions, mainly due to insulin antagonism, and into slow anabolic actions. The slow hypertrophic effects of GH are mediated via IGF-I. In this respect it is interesting to note that children with primary hypothyroidism have low plasma IGF-I levels compared with concentrations during therapy with L-thyroxine (Chernausek \& Turner 1989). Reduced circulating IGF-I levels have also been reported in hypothyroid rats (Osorio et al. 1998, Ramos et al. 1998). The low circulating IGF-I levels probably reflect the reduced GH secretion in these children and rats. In contrast, the results of this study demonstrate that the plasma IGF-I levels in dogs with primary hypothyroidism were significantly higher than those in the euthyroid state. The significantly elevated plasma IGF-I levels indicate that the elevated GH secretion in the hypothyroid dogs has systemic endocrine effects. Another indication that the elevated GH secretion has endocrine significance concerns the physical changes observed in dogs with primary hypothyroidism. Both in dogs with acromegaly (Rijnberk 1996) and in dogs with primary hypothyroidism, the physical features are characterized by thick skin folds. In acromegaly the skin thickening has been ascribed to mucopolysaccharide accumulation (Matsuoka et al. 1982). Similarly, in dogs with primary hypothyroidism the thickening of the skin is also due to mucopolysaccharide accumulation (Muller et al. 1989, Doliger et al. 1995). Thus, some of the physical changes observed in dogs with primary hypothyroidism might very well be acromegalic changes.

To summarize, the results of this study demonstrate that primary hypothyroidism in dogs is associated with elevated basal GH secretion and less GH secreted in pulses. This elevated $\mathrm{GH}$ secretion has endocrine significance as 
illustrated by elevated plasma IGF-I levels and some physical changes mimicking acromegaly. It is discussed that the increased GH release in hypothyroid dogs is the result of the absence of a response element for thyroid hormone at the canine pituitary GH gene and alterations in supra-pituitary regulation.

\section{Acknowledgements}

We are grateful for the technical assistance of Mrs M E van Wolferen, Mrs C P M Timmermans-Sprang, Mrs Ank van Wees, Mrs Y M E A Pollak and Mr H G H van Engelen.

\section{References}

Ahmad I, Steggles AW, Carrillo AJ \& Finkelstein JA 1989 Obesityand sex-related alterations in growth hormone messenger RNA levels. Molecular and Cellular Endocrinology 65 103-109.

Arvat E, Camanni F \& Ghigo E 1997 Age-related growth hormonereleasing activity of growth hormone secretagogues in humans. Acta Paediatrica Supplement 423 92-96.

Baldini M, Catania A, Orsatti A, Manfredi MG, Motta P \& Cantalamessa L 1992 Inhibitory effect of somatostatin on abnormal $\mathrm{GH}$ response to TRH in primary hypothyroidism. Experimental and Clinical Endocrinology 99 80-83.

Bermann M, Jaffe CA, Tsai W, DeMott-Friberg R \& Barkan AL 1994 Negative feedback regulation of pulsatile growth hormone secretion by insulin-like growth factor I: Involvement of hypothalamic somatostatin. Journal of Clinical Investigation $\mathbf{9 4}$ 138-145.

Breen JJ, Hickok NJ \& Gurr JA 1997 The rat TSHbeta gene contains distinct response elements for regulation by retinoids and thyroid hormone. Molecular and Cellular Endocrinology 131 137-146.

Bruhn TO, McFarlane MB, Deckey JE \& Jackson IMD 1992 Analysis of pulsatile secretion of thyrotropin and growth hormone in the hypothyroid rat. Endocrinology 131 2615-2621.

Bruner JM, Scott-Moncrieff JC \& Williams DA 1998 Effect of time of sample collection on serum thyroid-stimulating hormone concentrations in euthyroid and hypothyroid dogs. Journal of the American Veterinary Medical Association 15 1572-1575.

Buchanan CR, Stanhope R, Adlard P, Jones J, Grant DB \& Preece MA 1988 Gonadotrophin, growth hormone and prolactin secretion in children with primary hypothyroidism. Clinical Endocrinology 29 427-436.

Chernausek SD \& Turner R 1989 Attenuation of spontaneous, nocturnal growth hormone secretion in children with hypothyroidism and its correlation with plasma insulin-like growth factor I concentrations. Journal of Pediatrics 114 968-972.

Chomczynski P, Soszynski PA \& Frohman LA 1993 Stimulatory effect of thyroid hormone on growth hormone gene expression in a human pituitary cell line. Journal of Clinical Endocrinology and Metabolism 77 281-285.

Coiro V, Volpi R, Capretti L, Speroni, Marchesi C, Vescovi G, Caffarri G, Colla R, Rossi G, Davoli C \& Chiodera P 1994 Influence of thyroid status on the paradoxical growth hormone response to thyrotropin-releasing hormone in human obesity. Metabolism 43 514-517.

Corpas E, Harman SM \& Blackman MR 1993 Human growth hormone and human aging. Endocrine Reviews 14 20-39.

Damjanovic S, Popovic V, Petakov M, Djurovic M, Dieguez C \& Casanueva FF 1996 Pituitary enlargement due to primary hypothyroidism: growth hormone response to GHRH, GHRP-6 and GHRH plus GHRP-6. Journal of Pediatric Endocrinology and Metabolism 9 549-553.
Devesa J, Lima L \& Tresguerres JAF 1992 Neuroendocrine control of growth hormone secretion in humans. Trends in Endocrinology and Metabolism 3 175-183.

Doliger S, Delverdier M, More J, Longeart L, Regnier A \& Magnol JP 1995 Histochemical study of cutaneous mucins in hypothyroid dogs. Veterinary Pathology 32 628-634.

Eigenmann JE \& Eigenmann RY 1981 Radioimmunoassay of canine growth hormone. Acta Endocrinologica 98 514-520.

Eigenmann JE, Eigenmann RY, Rijnberk A, Van der Gaag I, Zapf J \& Froesch ER 1983 Progesterone-controlled growth hormone overproduction and naturally occurring canine diabetes and acromegaly. Acta Endocrinologica 104 167-176.

Elsasser TH, Rumsey TS \& Norton SA 1992 Relationships between the thyroid and somatotropic axes in steers I: effects of propylthiouracil-induced hypothyroidism on growth hormone, thyroid stimulating hormone and insulin-like growth factor I. Domestic Animal Endocrinology 9 261-271.

Eriksson L, Frankenne F, Eden S, Hennen G \& Von Schoultz B 1989 Growth hormone 24-h serum profiles during pregnancy - lack of pulsatility for the secretion of the placental variant. British Journal of Obstetrics and Gynaecology 96 949-953.

Faggiano M, Criscuolo T, Graziani M, Iorio S, Pisano G, Sinisi AA, Sinisi AM \& Bellastella A 1985 Persistent TRH-induced growth hormone release after short-term and long-term L-thyroxine replacement therapy in primary congenital hypothyroidism. Clinical Endocrinology 23 61-66.

Faria AC, Bekenstein LW, Booth RA Jr, Vaccaro VA, Asplin CM, Veldhuis JD, Thorner MO \& Evans WS 1992 Pulsatile growth hormone release in normal women during the menstrual cycle. Clinical Endocrinology 36 591-596.

Feldman EC \& Nelson RW 1996 Hypothyroidism. In Canine and Feline Endocrinology and Reproduction, edn 2, pp 68-117. Eds EC Feldman \& RW Nelson. Philadelphia: WB Saunders Co.

Fletcher TP \& Clarke IJ 1994 Effects of hypothyroidism on the growth hormone axis in sheep. Journal of Endocrinology 140 495-502.

French MB, Vaitkus P, Cukerman E, Sirek A \& Sirek OV 1987 Secretory pattern of canine growth hormone. American Journal of Physiology 252 268-272.

Frohman LA, Downs TR \& Chomczynski P 1992 Regulation of growth hormone secretion. Frontiers in Neuroendocrinology 13 344-405.

Hanew K, Utsumi A, Sugawara A, Tanaka A, Fukazawa H, Yoshida K \& Abe K 1995 Enhanced plasma GH responses to simultaneous administration of TRH and GHRH in patients with primary hypothyroidism. Endocrine Journal 42 43-47.

Hartman ML, Clayton PE, Johnson ML, Celniker A, Perlman AJ, Alberti KG \& Thorner MO 1993 A low dose euglycemic infusion of recombinant human insulin-like growth factor I rapidly suppresses fasting-enhanced pulsatile growth hormone secretion in humans. Journal of Clinical Investigation 91 2453-2462.

Hollenberg AN, Monden T, Flynn TR, Boers ME, Cohen O \& Wondisford FE 1995 The human thyrotropin-releasing hormone gene is regulated by thyroid hormone through two distinct classes of negative thyroid hormone response elements. Molecular Endocrinology 9 540-550.

Katakami H, Downs TR \& Frohman LA 1986 Decreased hypothalamic growth hormone-releasing hormone content and pituitary responsiveness in hypothyroidism. Journal of Clinical Investigation 77 1704-1711.

Kojima M, Hosoda H, Date Y, Nakazato M, Matsuo H \& Kangawa K 1999 Ghrelin is a growth-hormone-releasing acylated peptide from stomach. Nature 402 656-660.

Konaka S, Yamada M, Satoh T, Ozawa H, Watanabe E, Takata K \& Mori M 1997 Expression of thyrotrophin-releasing hormone (TRH) receptor mRNA in somatotrophs in the rat anterior pituitary. Endocrinology 138 827-830. 
Kooistra HS, den Hertog E, Okkens AC, Mol JA \& Rijnberk A 2000 Pulsatile secretion pattern of growth hormone during the luteal phase and mid-anoestrus in beagle bitches. Journal of Reproduction and Fertility 119 217-222.

Korytko AI \& Cuttler L 1997 Thyroid hormone and glucocorticoid regulation of pituitary growth hormone-releasing hormone receptor gene expression. Journal of Endocrinology 152 13-17.

Lamberts SW, Oosterom R, Verleun T, Krenning EP \& Assies H 1984 Regulation of hormone release by cultured cells from a thyrotropin-growth hormone-secreting pituitary tumor. Direct inhibiting effects of 3,5, $3^{\prime}$-triiodothyronine and dexamethasone on thyrotropin secretion. Journal of Endocrinological Investigation 7 313-317.

Lantinga-van Leeuwen IS \& Mol JA 2000 Cloning and characterization of the $5^{\prime}$ flanking region of the canine growth hormone gene. In Regulation of Growth Hormone Gene Expression in the Canine Mammary Gland, pp 81-90. Thesis of IS Langtinga-van Leeuwen, Utrecht University.

Lloyd RV, Jin L, Song JY, Terry LC, Horvath E \& Kovacs K 1990 Effects of propylthiouracil on growth hormone and prolactin messenger ribonucleic acids in the rat pituitary. Laboratory Investigation 62 347-354

Lovejoy JC, Smith SR, Bray GA, Veldhuis JD, Rood JC \& Tulley R 1997 Effects of experimentally induced mild hyperthyroidism on growth hormone and insulin secretion and sex steroid levels in healthy young men. Metabolism 46 1424-1428.

Martin D, Epelbaum J, Bluet-Pajot MT, Prelot M, Kordon C \& Durand C 1985 Thyroidectomy abolishes pulsatile growth hormone secretion without affecting hypothalamic somatostatin. Neuroendocrinology 41 476-481.

Martinoli MG \& Pelletier G 1989 Thyroid and glucocorticoid hormone regulation of rat pituitary growth hormone messenger ribonucleic acid as revealed by in situ hybridization. Endocrinology 125 1246-1252.

Matsuno M, Sohmiya M, Yamamoto H \& Kato Y 1998 An acromegalic patient with pulsatile secretion of growth hormone (GH) coincident with the slow-wave sleep. Endocrine Journal 45 687-692.

Matsuoka LY, Wortsman J, Kupchella CE, Eng A \& Dietrich JE 1982 Histochemical characterization of the cutaneous involvement of acromegaly. Archives of Internal Medicine 142 1820-1823.

Mendlewicz J, Linkowski P, Kerkhofs M, Leproult R, Copinschi G \& Van Cauter E 1999 Genetic control of 24-h growth hormone secretion in man: a twin study. Journal of Clinical Endocrinology and Metabolism 84 856-862.

Merriam GR \& Wachter KW 1982 Algorithms for the study of episodic hormone secretion. American Journal of Physiology 243 310-318.

Mizobuchi M, Ishikawa M, Okauchi Y, Bando H \& Saito S 1996 Effects of thyroidectomy on thyrotropin-releasing hormone (TRH) and somatotropin release-inhibiting factor (SRIH) patterns in intrahypophysial microdialysates in rats. Endocrine Journal $\mathbf{4 3}$ 679-687.

Morovat A \& Dauncey MJ 1998 Effects of thyroid status on insulin-like growth factor-I, growth hormone and insulin are modified by food intake. European Journal of Endocrinology 138 95-103.

Muller GH, Kirk RW \& Scott DW 1989 Cutaneous endocrinology. In Small Animal Dermatology, edn 4, pp 575-657. Eds GH Miller, RW Kirk \& DW Scott. Philadelphia: WB Saunders Co.

Nap RC, Mol JA \& Hazewinkel HAW 1993 Age-related plasma concentrations of growth hormone $(\mathrm{GH})$ and insulin-like growth factor 1(IGF-I) in Great Dane pups fed different dietary levels of protein. Domestic Animal Endocrinology 10 237-247.

Nishi Y, Hamamoto K, Kajiyama M, Fujita A, Kawamura I, Kagawa Y, Kajima T, Yamanaka M \& Uozumi T 1989 Pituitary enlargement, hypertrichosis and blunted growth hormone secretion in primary hypothyroidism. Acta Paediatrica Scandinavica 78 136-140.
Osorio A, Ruiz E \& Ortega E 1998 Possible role of GH/IGF-I in the ovarian function of adult hypothyroid rats. Molecular and Cellular Biochemistry 179 7-11.

Pimentel-Filho FR, Ramos-Dias JC, Ninno FB, Facanha CF, Liberman B \& Lengyel AM 1997 Growth hormone responses to GH-releasing peptide (GHRP-6) in hypothyroidism. Clinical Endocrinology 46 295-300.

Radoja N, Diaz DV, Minars TJ, Freedberg IM, Blumenberg M \& Tomic-Canic M 1997 Specific organization of the negative response elements for retinoic acid and thyroid hormone receptors in keratin gene family. Journal of Investigation in Dermatology 109 566-572.

Ramos S, Goya L, Alvarez C \& Pascual-Leone AM 1998 Mechanism of hypothyroidism action on insulin-like growth factor-I and -II from neonatal to adult rats: insulin mediates thyroid hormone effects in the neonatal period. Endocrinology 139 4782-4792.

Riedel M, Hoeft B, Blum WF, Von zur Muhlen A \& Brabant G 1995 Pulsatile growth hormone secretion in normal-weight and obese men: differential metabolic regulation during energy restriction. Metabolism 44 605-610.

Rijnberk A 1996 Hypothalamus-pituitary system. In Clinical Endocrinology of Dogs and Cats, pp 11-34. Ed. A Rijnberk. Dordrecht/Boston: Kluwer Academic Publishers.

Root JL, Duckett GE, Sweetland M, Strzelecki JA \& Root AW 1985 Hypothyroidism blunts the growth hormone $(\mathrm{GH})$ releasing effect of human pancreatic GH releasing factor in the adult male rat in vivo and in vitro. Endocrinology 116 1703-1706.

Rutteman GR, Stolp R, Rijnberk A, Loeffler S, Bakker JA, Bevers MM, Meulenberg PM \& Eigenmann JE 1987 Medroxy-progesterone acetate administration to ovariohysterectomized, oestradiol-primed beagle bitches. Effect on secretion of growth hormone, prolactin and cortisol. Acta Endocrinologica 114 275-282.

Santini F, Hurd RE, Lee B \& Chopra IJ 1993 Thyromimetic effects of 3,5,3'-triiodothyronine sulfate in hypothyroid rats. Endocrinology 133 105-110.

Selman PJ, Mol JA, Rutteman GR, Van Garderen E \& Rijnberk A 1994 Progestin-induced growth hormone excess in the dog originates in the mammary gland. Endocrinology 134 287-292.

Szabo M, Ruestow PC \& Kramer DE 1985 Growth hormone response to thyrotropin-releasing hormone in the urethaneanesthetized rat: effect of thyroid status. Endocrinology 117 330-337.

Takahashi Y, Ebihara S, Nakamura Y \& Takahashi K 1981 A model of human sleep-related growth hormone secretion in dogs: effects of 3,6 , and $12 \mathrm{~h}$ of forced wakefulness on plasma growth hormone, cortisol, and sleep stages. Endocrinology 109 262-272.

Takeuchi A, Suzuki M \& Tsuchiya S 1978 Effect of thyroidectomy on the secretory profiles of growth hormone, thyrotropin and corticosterone in the rat. Endocrinology 25 381-390.

Tam SP, Lam KS \& Srivastava G 1996 Gene expression of hypothalamic somatostatin, growth hormone releasing factor, and their pituitary receptors in hypothyroidism. Endocrinology 137 418-424

Van den Berg G, Veldhuis JD, Frolich M \& Roelfsema F 1996 An amplitude-specific divergence in the pulsatile mode of growth hormone $(\mathrm{GH})$ secretion underlies the gender difference in mean $\mathrm{GH}$ concentrations in men and premenopausal women. Journal of Clinical Endocrinology and Metabolism 81 2460-2467.

Van Garderen E, de Wit M, Voorhout WF, Rutteman GR, Mol JA, Nederbragt H \& Misdorp W 1997 Expression of growth hormone in canine mammary tissue and mammary tumors. Evidence for a potential autocrine/paracrine stimulatory loop. American Journal of Pathology 150 1037-1047.

Varela C, Cacicedo L, Fernandez G, de los Frailes T \& Sanchez Franco F 1991 Influence of hypothyroidism duration on developmental changes in the hypothalamic factors implicated in growth hormone secretion in the male rat. Neuroendocrinology 54 $340-345$. 
Watson ADJ, Rutteman GR, Rijnberk A \& Mol JA 1987 Effect of somatostatin analogue SMS 201-995 and antiprogestin agent RU486 in canine acromegaly. Frontiers of Hormone Research 17 193-198.

Williams T, Maxon H, Thorner MO \& Frohman LA 1985 Blunted growth hormone $(\mathrm{GH})$ response to $\mathrm{GH}$-releasing hormone in hypothyroidism resolves in the euthyroid state. Journal of Clinical Endocrinology and Metabolism 61 454-456.
Wood DF, Franklyn JA, Docherty K, Ramsden DB \& Sheppard MC 1987 The effect of thyroid hormones on growth hormone gene expression in vivo in rats. Journal of Endocrinology 112 459-463.

Received 21 July 2000

Revised manuscript received 13 September 2000 Accepted 28 September 2000 